DOI: $10.20472 /$ IAC.2018.001.001

\author{
PEERAYA ARNMANEE \\ Suan Sunandha Rajabhat University, Thailand \\ SANJAI SANGVICHIEN \\ Suan Sunandha Rajabhat University, Thailand
}

\title{
CUSTOMERS SATISFACTION OF THAI HERBAL BODY OIL
}

\begin{abstract}
:
This research aims 1) to study satisfaction of the customers who use Thai herbal body oil 2) the influence of the demographic factors on the customers' satisfaction. The study was carried out between January and March 2018. This study employed a quantitative research approach. The research sample consisted of 92 customers. A questionnaire was used to collect the data. The data were analyzed by descriptive statistics including frequency, percentage, mean and standard deviation, and inferential statistics. The Research result showed that: 1) the customers were satisfied with the product, the overall satisfaction was rated at a high level; and 2) demographic factors including age, gender, and salary, were found to have an influence on their satisfaction of the product.
\end{abstract}

\section{Keywords:}

Satisfaction, Herbal, Demographic, Factors

JEL Classification: Y80 


\section{Introduction}

If you look at the ingredients of skincare products in the market, the information about average ingredients will be listed by chemical composition which there is no guarantee that it will be hazard and make you irritate or not. Avoiding the hazardous chemical skincare products by using the natural products is essential.

The integrated medicine for skin treatment is one of alternative choices for beauty and health promotion. The integrated medicine is presently popular in every parts of the world including Thailand where the market scales of natural healthcare products, spa products as well as tourism services are now expanded. Getting information from the media, receiving social support from people who adopt healthy behaviors. (Saykaew,T.,2016) The integrated medicine and natural skincare products are popular because of its safety and properties. The ingredients of them are come from nature. For instance of Thai herbal body oil, the oil is come out and extracted from botanical organs such as corolla, fruit, seed, bark, leaf, pod, stem which the medical properties of the extracted oil can used for relieving the muscle pain, inflammation as well as emotional relaxation.

This research will focus on the customers satisfaction of Thai herbal body oil. The outcome of this research can be contributed to a direction or pathway for product development in eventually.

\section{The Methodology and Model}

The study is a survey research. The targeted population in this research is 120 customers who are health service users at the Applied Thai Traditional Medicine Clinic in Bangkok. According to Yamane's method (1970), sample size of this paper is 92 patients which are referred by probability sampling (systematic sampling).

1.The variables in this research comprise of independent and dependent variables.

Independent variable is demographic characteristics which is consisted of gender, age, occupation, and salary, whereas the dependent variables are:

1.1Satisfactions on Thai herbal body oil are sub-divided into 2 parts of services and types of product.

1.2Treatment suitability are concentrated to skill, convenience, instrument, and herbal products.

2.The research instrument is a satisfaction evaluation form (questionnaire) which is distributed to the customer at the Applied Thai Traditional Medicine Clinic. The questionnaire has three series of questions. 
Series 1, questions are about demographic characteristics; gender, age, occupation, and salary. There is 4 check-list questions.

Series 2, questions are about the levels of satisfaction on the customer who use Thai herbal body oil at the Applied Thai Traditional Medicine Clinic to measure 2 parts. There are totally 10 questions which the rating scales are followed the Likert's method. Likert scale format is "Very satisfied", "Satisfied", "Neither satisfied nor dissatisfied", "Dissatisfied", and "Very dissatisfied".

Series 3 , focuses on the treatment suitability. There is also divided into 2 parts and 10 questions in total which the rating scales are followed the Likert's method; "Extremely", "Very", "Moderately", "Slightly", and "Not at all".

Series 4 is an open-end questionnaire for outpatients which requires the patients' comments.

\section{Research instrument assessment}

Research instrument assessment is to determine the validity and reliability on the questionnaire. Assessment is required from 3 experts and 30 try-out cases at the reliability .9502.

4.Data collection - distributes 92 questionnaires to customer who use the products at the Applied Thai Traditional Medicine Clinic.

5.Research analysis - rechecks the completion of the returned questionnaires and analyzes and interprets by using the statistic package.

5.1 Descriptive statistics are used to describe the basic features of the personal data. There are percentage, mean and standard deviation.

5.2 Inferential statistics are used to deduce from the sample data. This statistic is to investigate the difference between 2 sample groups which is consisted of independent sample t-test and one-way analysis of variance. In case, there are the significant differences, the Least Significant Difference (LSD) will be tested at the significant level .05.

\section{The Findings}

1. 92 customers at Applied Thai Traditional Medicine Clinic in Bangkok were mostly 32-40 years old females, who were working in the private companies and earning 25,001-35,000 Baht a month. 
2. The customers at Applied Thai Traditional Medicine Clinic in Bangkok were very satisfied with Thai herbal body oil and preferred to overall services as shows in the Table 1.

Table 1 Statistics of customers' satisfaction in Thai herbal body oil at Applied Thai Traditional Medicine classified by field of services

\begin{tabular}{lccc} 
Satisfaction in Thai herbal body & \multicolumn{3}{c}{ Level of satisfaction } \\
\cline { 2 - 5 } & $\bar{x}$ & S.D. & $\begin{array}{c}\text { Data } \\
\text { interpreting }\end{array}$ \\
\hline 1 Services & 3.95 & .195 & Satisfied \\
2 Types of product & 3.92 & .193 & Satisfied \\
\hline Overall & 3.93 & .154 & Satisfied \\
\hline
\end{tabular}

2. Factors that influenced the customers' satisfaction in Thai herbal body oil at Applied Thai Traditional Medicine Clinic were classified by the demography such as Gender, Age, Occupation, and salary.

The results showed that the customers/users at Applied Thai Traditional Medicine Clinic who were different genders and ages were not different satisfactions in Thai herbal body oil. Besides, the users who were different occupations and salaries were different satisfactions in the services as shows in the Table 2

Table 2 Comparison on the customers' satisfaction in Thai herbal body oil at Applied Thai Traditional Medicine classified by fields of services, overall, demography

\begin{tabular}{lcccc}
\hline \multirow{2}{*}{ factor } & \multicolumn{2}{c}{ Product use } & \multicolumn{2}{c}{ Types of products } \\
\cline { 2 - 5 } & Statistics & $\mathrm{p}$-value & Statistic & $\mathrm{p}$-value \\
\hline Gender & $\mathrm{t}=.839$ & .404 & $\mathrm{t}=-.031$ & .976 \\
\hline Age & $\mathrm{F}=.678$ & .568 & $\mathrm{~F}=1.104$ & .352 \\
\hline Occupation & $\mathrm{F}=.595$ & .620 & $\mathrm{~F}=3.498^{\star}$ & .019 \\
\hline Salary & $\mathrm{F}=.734$ & .535 & $\mathrm{~F}=4.310^{*}$ & .007 \\
\hline
\end{tabular}

*Significant level 0.05 


\section{Acknowledgement}

The author would like to thank the graduate school and Suansunandha Rajabhat University for the support. The author would also like to thank the university SSRU executives, Associate Professor Dr. Luedech Gerdwichai, the president and assistant professor Dr. Duangsamorn Rungsawanpho, Dean of Graduate School and all the people who are respondents that have participated in the research.

\section{References}

Abdellah, Faye G. and Levine, Eugene,1957,100-108. "Developing a Measure of Patient and PersonelSatisfaction with Nursing Care.", Nursing Research 2.

Barrett,Jean et al.,1975, The Head Nurse. New York : Appleton Century Crofts.

Chang, K. 1997, 26-37,Dimensions and indications of patients' perceived nursing care quality in Hospital setting. Journal of Nursing Care Quality 11.

Davis, Kaith.1967,Human Relation at Work : The Dynamic of Organizational Behavior. NewYork : Mc Graw-Hill Book Company.

Densky,K.H.,1997,165-172.,Patient satisfaction with ambulatory health care service : waiting time and Filling time. Hospital \& Health Service Administration 2.

De Walfe, Alan S et al.,1966,68-72 "Patient Variable in Emotional Response to Hospitalization for Physical IIIness",Journal of Consulting Psychology. Donabedian, A.,1985,165-183,Twenty years of research on the quality of medical care. Evaluation andThe health Professions 2.

Durr, Carol A.,1971,392-400, "Hands that Help .....but How." Nursing Forum 4.

Hay, Stella I., and Anderson, Helen C.,1963,96-99 “Are Nurses Meeting Patiens Needs." The American Journal of Nursing 12.

Kraegel, Janet M et al. 1972,257-264 "A System of Paitient Care Based on Patien Needs." NursingOutlook 4.

Linder-Pelz, Susie. 1982 ,579-582. "Toward A Theory of Patient Satisfaction ." Social Science Medicine16.

Loeken, $K$ et al.,1997,731-741, A new instrument to measure patient Satisfaction with mammography.Medical care 35.

Mangelsdorff, A.,1979,86-90, "Patient Satisfaction Questionnair." Medical Care 17. 
Morse, Nancy C. Satisfaction in the White Collar Job. Michigan : University of Michigan Press.

Pollert, Irene E.,1971,135-144, " Expeetation and Discrepancies With Hospital Condition as They Actally Exist." Intarnal Journal of Nursing Studies 8.

Rine, Alice R.,1976,and Montag, Mildred C. Nursing Concepts and Nursing Care. New York :John Wiley and son.

Risser, Nancy C.,1975,45-51, " Development of an Instrument to mwasure Patien Satisfaction with Nurse and Nursing Care in Primary Care Setting." Nursing Research24.

Saykaew,T.,2016,1749-1763, "Factors Associated with 3E's, 2S's of Village Health Volunteers in Bang Khonthi District, Samutsongkhram Province", $5^{\text {th }}$ suan sunandha Academic national conferences on research for sustainable Development. 